\title{
Coconut Cryopreservation: Present Status and Future Prospects
}

\author{
Iroshini Welewanni ${ }^{1}$, Anil Jayasekera ${ }^{1}$, Dharshani Bandupriya ${ }^{2 *}$
}

\begin{abstract}
Coconut is one of the most important small holder crops worldwide. Conservation of coconut as seeds or field gene banks is not effective due to a range of limitations. Cryopreservation, which is the conservation of living propagules at very low temperature $\left(-196^{\circ} \mathrm{C}\right)$, is the only method available currently for the long-term conservation of germplasm for problem plant species such as recalcitrant and vegetatively propagated plant species. This review summarizes different cryopreservation techniques that have been published from 1984 until the present in relation to different coconut material; it includes a brief discussion about short and medium-term cryopreservation before describing long-term preservation. It discusses factors affecting the process and success of cryopreservation, such as selection of plant material, pre-culture of tissues, osmoprotection, dehydration, cryo-storage, thawing and post-culturing of tissues, and finally to plants. The review also describes histological and ultra-structural studies on and the use of molecular markers to assess genetic stability after cryopreservation. Limitations and future directions related to coconut cryopreservation are discussed. Additional experiments are identified that will need to be undertaken to improve our understanding of the different cryopreservation methods.
\end{abstract}

Key words: Coconut germplasm; Medium-term conservation; Long-term conservation; Plant material; cryopreservation technique

\section{Introduction}

Conservation or preservation of the genetic diversity of a particular plant is vital to maintain its diversity for future use thus plays an important role in all breeding programmes. However, certain kinds of conservation lead to loss of crop diversity due to natural disasters (droughts, floods, Tsunami and cyclones), deforestation, urbanization, fragmentation and degradation, globalization, climate change, pest and disease attacks and change in land use patterns (Rao, 2004). Coconut (Cocos nucifera L.) being a major perennial oil crop in the tropics and by providing food and industrial products, plays a great role in the socioeconomic life of small holder farmers in this region. Coconut is one of the most extensively grown and used palms which is cultivated in more than 92 countries around the world. The total area of the cultivated land in the world is 12.19 million ha and the annual total coconut production is around 69,836 million nuts (Coconut Statistical Year Book APPC, 2014). As a result of previously explained reasons, coconut is facing the problem of losing valuable germplasm which could be of great value in future breeding programs.

\footnotetext{
${ }^{1}$ Department of Plant Sciences, Faculty of Science, University of Colombo, Colombo 03, Sri Lanka. Email: jayasekeraanil@yahoo.com; Ir_zziroshizz@gmail.com

${ }^{2 *}$ Tissue Culture Division, Coconut Research Institute, Lunuwila, Sri Lanka. Email: dbandupriya@yahoo.com; Tel.: +94 312262003
} 
Conservation of plant genetic resources is done either in natural habitats where plants are located (in situ) or outside their natural habitats (ex situ). Approaches to ex situ conservation include storage in seed gene banks, field gene banks, botanical gardens and DNA and pollen storage; of these seed storage is the most convenient method. However, conventional storage as seed is impossible in coconut because of the large size, recalcitrant nature and most importantly the lack of a dormancy period (Engelmann, 1999). According to the International Coconut Genetic Resources Network's (COGENT) Coconut Genetic Resources Database (CGRD), coconut germplasm is conserved only in field gene banks in ex situ conditions in 25 sites in 23 countries around the world, which conserve about 1416 accessions (Engelmann et al., 2005). Two hundred important accessions are conserved in the countries where India, Indonesia, Papua New Guinea, and Côte d'Ivoire and Brazil by a multisite International Coconut Genebank (ICG) which COGENT operates. However, this type of conservation requires a very large area for the maintenance and the process is highly labour intensive and thus very costly. Other problems include the fact that field gene banks are always under the threat of adverse weather conditions and pest and disease attacks (Engelmann, 1997). For this reason, there is great potential in in vitro culture techniques for the collecting, exchange and conservation of plant germplasm. In vitro conservation should be given particular priority for the problem plant species, which consist of those with recalcitrant seeds and those that are propagated vegetatively (Engelmann, 1997, 2000). Therefore, the development of in vitro methods is very important for conserving coconut genetic resources in order to protect the existing coconut diversity and elite genotypes (Engelmann, 2011) and lead to crop improvement and avoid genetic erosion.

Cryopreservation is a method of conserving plant tissues at an ultra-low temperature, usually that of liquid nitrogen ($\left.196^{\circ} \mathrm{C}\right)$. Living plant cells contain large quantities of water and they are extremely sensitive to low temperatures. The most critical step in cryopreservation of biological tissues is the removal of the intracellular water fraction which is capable of converting into ice crystals during freezing in liquid nitrogen. Such crystals cause irreversible damage to cell membranes, destroying the semi-permeable nature of cells (Panis and Lambardi, 2006). Under ultra-low temperature, metabolic processes and cell divisions are arrested and this results in conservation of plant tissues for an unlimited period of time. Cryopreservation is used for long-term preservation of genetic resources in many plant species and provides maximum stability of phenotypic and genotypic characters (Steponkus, 1985). There are many advantages in cryopreservation when compared with the conventional field gene banks; these advantages include the low costs of storage, minimal space requirements and less labour maintenance (Engelmann et al., 2005). The major advantages are simplicity and the possibility of application for a wide range of genotypes (Engelmann, 2004). In addition, there is no risk of new contamination by fungus or bacteria, after the storage (Engelmann, 1991; 2003). Cryopreservation is employed not only for germplasm conservation, but also for cryoselection, (the selection through freezing of samples with special properties) and for cryotherapy (the elimination of viruses from infected plants through apex cryopreservation) (Engelmann, 2004). Another advantage of cryopreservation is to conserve endangered plant species, particularly where seeds may be extremely scarce or of doubtful quality and the species is threatened with imminent extinction (Mallon et al., 2008; Paunescu, 2009; Sen-Rong and Ming-Hua, 2009; Engelmann, 2011).

As mentioned, cryopreservation is mainly used for recalcitrant (non-orthodox) seeds and for vegetatively propagated plants. Long-term storage of seeds is quite impossible for most seed types due to their recalcitrant characteristics (Roberts 1973; Chin and Roberts 1980). Recalcitrant seeds are sensitive to desiccation, thus they can be stored only for a short period of time, with a maximum of weeks to months even under optimal moisture and temperature conditions. Orthodox species can be dehydrated 
and cryopreserved at low moisture levels (3-5\% of tissue fresh weight) without causing damage while recalcitrant species do not survive dehydration below 30-50\% of fresh weight (Bajaj, 1995). In the 1990s, conservation of coconut germplasm was mainly focused on ex situ conservation through in vitro techniques employing zygotic embryos and pollen (Frison et al., 1993; Malaurie, 2001) due to limitations associated with seed banks and field gene banks. Thereafter, it became focused on the plumules but not yet for other type of tissues. At present, success of tissue recovery is limited and it varies on the different varieties (Sisunandar et al. 2010a). Two reports have only been reported for the establishment of plants in soil following cryopreservation of coconut embryos (Sajini et al., 2011; Sisunandar et al., 2010b). Thus, this paper summarizes the present status of different techniques deployed in cryopreservation of coconut and possible future directions of research which would lead to better techniques in cryopreservation of coconut.

\section{Techniques used on coconut cryopreservation}

There have been a limited number of studies conducted to develop a cryopreservation technique in coconut by different research teams in Australia, Côte d'Ivoire, France, India, Malaysia, Sri Lanka, United Kingdom and Korea. Several techniques have been deployed for cryopreservation of different plant materials of coconut (Table 01). The first attempt of cryopreservation coconut tissues was deployed with immature zygotic embryos using a classical cryopreservation protocol which consisted of chemical dehydration and slow freezing techniques (Bajaj 1984). Later on, Chin et al. (1989) also used this method for immature zygotic embryos. These classical cryopreservation protocols include several steps such as pregrowth, chemical dehydration, slow cooling $\left(0.5-2.0^{\circ} \mathrm{C}\right.$ minute-1) to a determined prefreezing temperature (usually around $-40^{\circ} \mathrm{C}$ ) by using programmable freezing apparatus, rapid immersion of samples in liquid nitrogen, storage, rapid thawing and recovery (Engelmann, 2011). Chemical dehydration can be done mostly using polysaccharides (sucrose, glucose and glycerol) at high concentrations, or dimethyl sulfoxide (DMSO) and sorbitol are less frequently used (Nguyen et al., 2015). During slow cooling, initially the cells and the external medium is supercooled forming ice in the medium (Mazur, 1984). The cell membrane acts as a physical barrier and prevents freezing of the cell interior, which is maintained in a super cooled and unfrozen state. When the temperature is gradually reduced, the amount of ice converted by the extracellular solution increased and results in an increase in concentration of the intracellular solutes. Then the aqueous vapour pressure of cells increases, and most or all of the water leaves the cells before the intracellular contents solidify in optimum conditions; this avoids intracellular ice crystal formation after liquid nitrogen application (Engelmann and Dussert, 2013).

Majority of the cryopreservation work on coconut has been carried out by using desiccation or pregrowth desiccation techniques which are vitrification-based techniques. In vitrification-based techniques, desiccation is carried out, by exposing samples to a cryoprotection solution or by air desiccation and this is followed by direct immersion in liquid nitrogen. There are several techniques in this category; these include pregrowth, pregrowth desiccation, dehydration, encapsulationdehydration, vitrification, encapsulationvitrification and droplet vitrification. These techniques have several advantages such as being simple, widely applicable, having no need for expensive equipment and being more suitable for organized structures than classical techniques (Mandal, 2003). The major difference in desiccation and pregrowth desiccation techniques; in pregrowth desiccation the plant materials are pregrown in the presence of cryoprotectants (e.g. glucose; glycerol) followed by physical dehydration and freezing, whereas in desiccation the plant materials are directly dehydrated physically and frozen. Physical dehydration can be attempt by two ways; slow physical dehydration (in a laminar air flow hood), and fast physical dehydration (air drying using silica gel). Slow physical dehydration using silica gel under lamina air flow has been 
showed relatively high recovery with less plantlet production whereas the rapid physical dehydration using a special apparatus have been showed certain plantlet production (Sisunandar et al., 2010b; Nguyen et al., 2015).

Dehydration is the simplest procedure for desiccation of the explants. However, there is no control of temperature and air humidity (Panis et al., 2001). It should be noted that removal of water through dehydration can cause cell injury; too much dehydration causes cell injury due to membrane stress while too little dehydration causes intracellular freezing due to cell membrane rupture as a result of a $10 \%$ increase in volume after ice formation (Crowe et al., 1988; Chaudhury, 2003). Thus the tissue needs to be dehydrated properly to prevent cell damage. This method is mainly applied for zygotic embryos and pollen grains in coconut across a number of coconut cultivars and plantlet production is very low.

Encapsulation-dehydration using coconut plumules has been first attempted by Hornung et al. in 2001. Later, Malaurie et al. (2002) Bandupriya et al. (2007) and N'Nan et al. (2008) also conducted research on encapsulationdehydration, however not succeeded up to field grown level. This method is based on the production of artificial seeds, a process that involves embedding the plant material in calcium alginate beads. This method was developed by Fabre and Dereuddre in 1990. The beads are pre-grown in a liquid medium enriched with sucrose for several days, partially desiccated using silica gel and dried down to 20$30 \%$ of moisture content. This comprises the gradual removal of freezable cell water from the tissue, because the method requires cryogenic storage in the total absence of ice (Benson et al., 1996). These beads are used to protect the plant material from dehydration and freezing (Fabre and Dereuddre, 1990). The nutritional properties of the bead promote the regrowth of the explant after culturing (Panis and Lambardi, 2006). Preculture on sucrose enriched medium prior to encapsulation, usually improves survival after desiccation and freezing. Finally the beads are frozen rapidly in liquid nitrogen, rewarmed and cultured in standard growth medium to assess the post-thaw survival and recovery of plant tissues (Engelmann and Dussert, 2013). The disadvantages of this method are its long duration and the labour intensive nature of the procedure for handling alginate beads.

Moreover, few reports on vitrification method are recorded (Sajini et al., 2011; Cueto et al., 2013) in coconut. The first report of vitrification solution with plant tissues appeared in 1989 (Langis et al., 1989; Uragami et al., 1989) and now it is the most widely used cryopreservation protocol. Vitrification is a method of treating explants with a concentrated vitrification solution for different periods of time, followed by direct immersion in liquid nitrogen (Panis and Lambardi, 2006). Vitrification removes most or all freezable water from explants by physical or osmotic dehydration. During the liquid nitrogen application, intracellular solutes are vitrified, and form an amorphous glassy structure with an absence of ice crystals, thus preventing cell damages (Kaviani, 2011). A rapid and very precisely timed pretreatment which is very high cryoprotectant concentration is the main requirement in vitrification (Engelmann, 1991). The most commonly applied solutions, named "Plant Vitrification Solution 2 (PVS2)" (Sakai et al. 1990) and "Plant Vitrification Solution 3 (PVS3)" (Nishizawa et al. 1993), contain a mixture of penetrating and non-penetrating cryoprotectant substances. Following the development of the original solutions, Kim et al. (2009) have produced a series of alternative vitrification solutions, which produce higher survival and recovery. Preculture in high sucrose and treatment with loading solution give benefits in by improving desiccation tolerance and reducing toxicity with the vitrification solution. Advantages of this method are its simplicity, high reproducibility and wide application in tissues and plants (Panis and Lambardi, 2006), while the main problem is toxicity of the concentrated solutions. One report was found for the cryopreservation through droplet-vitrification by Cueto et al., (2013). Droplet-vitrification is the latest technique (Panis et al. 2005) and is based on a standard vitrification method but with a different freezing approach. For the freezing 
Table 1. Use of different plant materials in different cryopreservation techniques for coconut

\begin{tabular}{|c|c|c|}
\hline Plant material & Reference & Method \\
\hline Pollen & $\begin{array}{l}\text { Frison et al., } 1993 \\
\text { Assy-Bah B (unpublished) } \\
\text { Karun et al., 2006; } \\
\text { Karun and Sajini, } 2010 \\
\text { Machado et al., } 2014 \\
\text { Karun et al., } 2014\end{array}$ & $\begin{array}{l}\text { Conditioning and desiccation } \\
\text { Partial desiccation } \\
\text { Incubator dried + cryopreservation } \\
\text { Incubator dried + cryopreservation } \\
\text { Storage at low temperatures } \\
\text { Desiccation }\end{array}$ \\
\hline Immature zygotic embryos & $\begin{array}{l}\text { Bajaj, } 1984 \\
\text { Chin et al., } 1989 \\
\text { Assy-Bah and Engelmann, 1992a }\end{array}$ & $\begin{array}{l}\text { Classical cryopreservation } \\
\text { Classical cryopreservation } \\
\text { Pregrowth desiccation }\end{array}$ \\
\hline Mature zygotic embryos & $\begin{array}{l}\text { Assy-Bah and Engelmann, 1992b } \\
\text { N'Nan, } 1997 \\
\text { Jayasingha } \text { et al., } 2002 \\
\text { N'Nan, } 2003 \\
\text { Karun } \text { et al., } 2005 \\
\text { Sajini } \text { et al., } 2006 \\
\text { Sisunandar } \text { et al., 2010a } \\
\text { Sisunandar } \text { et al., 2010b } \\
\text { Sajini et al., } 2011 \\
\text { N'Nan } \text { et al., } 2012 \\
\text { Sisunandar, } 2013 \\
\text { Sisunandar } \text { et al., } 2014 \\
\text { Cueto } \text { et al., } 2013\end{array}$ & $\begin{array}{l}\text { Pregrowth desiccation } \\
\text { Pregrowth desiccation } \\
\text { Pregrowth desiccation } \\
\text { Pregrowth desiccation } \\
\text { Desiccation } \\
\text { Pregrowth desiccation } \\
\text { Dehydration } \\
\text { Dehydration } \\
\text { Vitrification } \\
\text { Simple desiccation } \\
\text { Physical dehydration } \\
\text { Dehydration } \\
\text { Droplet vitrifiation, Vitrification and } \\
\text { Preculture-desiccation }\end{array}$ \\
\hline Plumule & $\begin{array}{l}\text { Bandupriya et al., } 2007 \\
\text { N'Nan et al. } 2008 \\
\text { Malaurie et al., } 2006 \\
\text { Bandupriya et al., } 2010 \\
\text { Alla-N'Nan O et al., 2014a } \\
\text { Alla-N'Nan O et al., 2014b }\end{array}$ & $\begin{array}{l}\text { Encapsulation/dehydration } \\
\text { Encapsulation/ osmoprotection/ } \\
\text { dehydration and encapsulation/ } \\
\text { osmoprotection/vitrification } \\
\text { Encapsulation/dehydration } \\
\text { Encapsulation/dehydration } \\
\text { Encapsulation/dehydration } \\
\text { Encapsulation/dehydration } \\
\text { Encapsulation/dehydration } \\
\text { Encapsulation/dehydration }\end{array}$ \\
\hline
\end{tabular}


process, samples are placed on aluminum foil and minute droplets of vitrification solution are added, followed by rapid immersion in liquid nitrogen with direct contact (Engelmann and Dussert, 2013; Sakai and Engelmann, 2007).

\section{Coconut plant material selection for cryopresrvation}

A very limited number of tissues, such as pollen, zygotic embryos and plumules have been tested for their ability to undergo cryopreservation in coconut. However, different plant parts are used for cryopreservation in different plant species; these include callus [Dioscorea bulbifera L. (Ming-Huaand SenRong, 2010); Ginkgo biloba (Popova et al., 2009); Emmenopterys henryi Oliv (Sen-Rong and Ming-Hua, 2012)]; cell cultures [Ginkgo biloba (Lu et al., 2009); grapevine (Vitis spp.) (Wang et al., 2004)]; shoot tips [in vitro-grown apple (Feng et al., 2013); Rabdosia rubescens (Ai et al., 2012)]; somatic embryos [Camellia (Janeiro et al., 1997); conifer (Kong and Aderkas, 2011); horse chestnut (Jekkel et al., 1998)] zygotic embryos in coffee and oil palm (Engelmann et al., 1995); pollen in date palm (Mortazavi et al., 2010).

\subsection{Pollen}

Cryopreservation of coconut pollen was first reported by Frison et al. (1993) and it was subsequently reported with practicable recommendations of collecting, conditioning and cryogenic storage (Engelmann, 1999; Hocher et al., 2004). In Côte d'Ivoire, preliminary unpublished research work performed by AssyBah showed coconut pollen is amenable to cryopreservation after partial desiccation (Engelmann et al., 2005). Coconut germplasm exchange in the form of pollen has been examined by Karun et al. by assessing viability at low and ultra-low temperatures (Karun et al., 2006; Karun and Sajini, 2010). According to that report, $38.54 \%$ germination was observed from the medium containing $8 \%$ sucrose, $1 \%$ gelatin, $1 \%$ agar and $0.01 \%$ boric acid (Karun et al., 2006). In addition, research carried out by Machado et al. in Brazil to assesses the pollen grain viability of coconut accessions at low temperatures under different storage conditions [refrigerator $\left(-4^{\circ} \mathrm{C}\right)$; freezer $\left(-20^{\circ} \mathrm{C}\right)$; ultra-freezer $\left(-80^{\circ} \mathrm{C}\right)$ and liquid nitrogen $\left.\left(-196^{\circ} \mathrm{C}\right)\right]$ has reported that pollen of Brazilian Tall (BRA) shows a significant effect on storage conditions and storage times (Machado et al., 2014). A higher viability for pollen germination $(81.93 \%)$ upon storage in liquid nitrogen has been reported in this study. However, these results are greater than that of observed by Karun and Sajini (2010) for West Coast Tall (WCT) coconut accessions after the storage of pollen in liquid nitrogen for $0,1,2$, and 3 years $(32.07,32.16,40.05$ and $34.32 \%$, germination respectively). A recent study carried out for testing the effect of cryostorage duration on coconut pollen germination and fertility has shown only $26-$ $29 \%$ germination in the variety Chowghat Orange Dwarf (COD) once the pollen is dehydrated to reduce the water content up to $7.5 \%$ followed by direct immersion in liquid nitrogen (Karun et al., 2014).

\subsection{Zygotic embryos}

\section{Immature zygotic embryos}

The first studies in 1984 for coconut cryopreservation using immature zygotic embryos $(1-1.5 \mathrm{~cm})$ from West Coast Tall cultivars in India (Bajaj, 1984) were not successful. Two explants, whole embryo and transverse halves of embryos were used and showed a limited survival (17-25\% respectively). Although zero recovery was observed in these immature zygotic embryos, the appearance of embryo swelling, elongation and proliferation on halves of transversally cut embryos indicated the possibility of long-term conservation of coconut germplasm. DMSO (7\%) and sucrose (4\%) have been used as cryoprotectants in the above study. Germination of a single embryo 15 months after freezing was reported by Chin et al. (1989) using DMSO $(10 \%)$ along with glycerol $(10 \%)$ in a classical cryopreservation protocol. This method is mostly used for undifferentiated culture systems such as cell suspensions and calluses (Kartha and Engelmann 1994; Withers and Engelmann 1998) and apices of cold-tolerant species (Reed and Uchendu, 2008). Thus, zygotic embryos subjected to classical freezing methods may not withstand the stress created 
during freezing and this might be the reason for their low survival reported in the above study.

In the 1990s, immature zygotic embryos of coconut (7-8 months after pollination) have been tested for the cryopreservation through pregrowth desiccation method (Assy-Bah and Engelmann, 1992a). In this experiment, embryos withstood rapid freezing in liquid nitrogen after four hours of pregrowth on a semi-solid medium containing $600 \mathrm{gL}^{-1}$ glucose and 10 or $15 \%$ glycerol or sorbitol. In these conditions, 10 to $43 \%$ survival was recorded and one embryo developed into a rooted plantlet after two and half months of freezing. Here the results showed high survival rates but limited recovery of plantlets due to the inadequate recovery conditions (Assy-Bah and Engelmann, 1992a).

\section{Mature zygotic embryos}

The first protocol has been reported on cryopreservation of mature zygotic embryos (1012 months after pollination) employing four different coconut genotypes [Hybrid PB121, Cameron Red Dwarf (CRD), Renell Tall (RT) and Indian Tall (IT) which involved a pregrowth desiccation. In this study it is reported that recovery percentages ranging from $33 \%$ to $93 \%$ in four different coconut genotypes (Assy-Bah and Engelmann 1992b). This method involves a four hours desiccation period under laminar flow cabinet followed by an 11-20 h culture on a medium $\left(600 \mathrm{gL}^{-1}\right.$ glucose and $15 \%$ glycerol $)$ and freezing. These results were validated later with West African Tall (WAT) and Malayan Yellow Dwarf (MYD) (N'Nan, 1997) and ten more other ecotypes (N'Nan et al., 2003). A study of Karun et al. (2005) and Sajini et al. (2006) performed similar studies using West Coast Tall variety cryopreserved by desiccation and pre-growth desiccation respectively; however recovery percentages recorded in this study were low (20\% and $29 \%$ respectively) compared to previously reported results.

A pregrowth desiccation technique has been used to determine the feasibility of using Sri Lankan Tall variety for cryopreservation of mature zygotic embryos; the highest recovery $(60 \%)$ was recorded when the embryos were treated for $10 \mathrm{~h}$ desiccation by silica gel followed by $15 \mathrm{~h}$ cryoprotective treatment in a solution containing $600 \mathrm{~g} \mathrm{~L}^{-1}$ glucose and $15 \%$ glycerol (Jayasingha et al., 2002). In a more recent study, Sisunandar et al. (2010b) reported up to $40 \%$ plantlet production after cryopreservation of embryos using a modified desiccation protocol. In this study the feasibility of the protocol was first assessed on Malayan Yellow Dwarf (MYD) cultivar then tested on a range of Indonesian cultivars. A higher number of viable plantlets were generated after a rapid dehydration technique applied for 8 hours followed by a rapid freezing approach. Success of the protocol also depended on the rapid warming step and the optimized in vitro culture protocol. Recovery of cryopreserved embryos also depended on the duration after harvesting. Embryos cryopreserved as soon as nuts are harvested showed twice the recovery (40\%) compared to the embryos cryopreserved 12 days after harvesting. The thermal properties of water within the embryos were monitored using Differential Scanning Calorimetry (DSC), in order to confirm the freezable water content was very low. DSC showed that this protocol induces a drop of embryo fresh weight up to $19 \%$ thus significantly reducing the amount of water remaining and which could convert into ice crystals $(0.1 \%)$.

Sajini et al. (2011) have reported on the effect of preculture conditions, vitrification and unloading solutions on survival and regeneration of coconut zygotic embryos after cryopreservation. According to this study, amongst seven plant vitrification solutions PVS3 is the most effective cryoprotectant. The treatment comprises preculturing embryos for three days on a medium with $0.6 \mathrm{M}$ sucrose, PVS3 treatment for 16 hours, rapid cooling, rewarming and unloading in a $1.2 \mathrm{M}$ sucrose liquid medium for 1.5 hours, gave $70-80 \%$ survival and $20-25 \%$ of plant regeneration and was recorded as the best treatment (Sajini et al., 2011).

A simple and efficient cryopreservation protocol for coconut mature zygotic embryos has been developed for a large number of accessions (N'Nan et al., 2012). In this study embryos inoculated in petri dishes containing $3.2 \mathrm{M}$ 

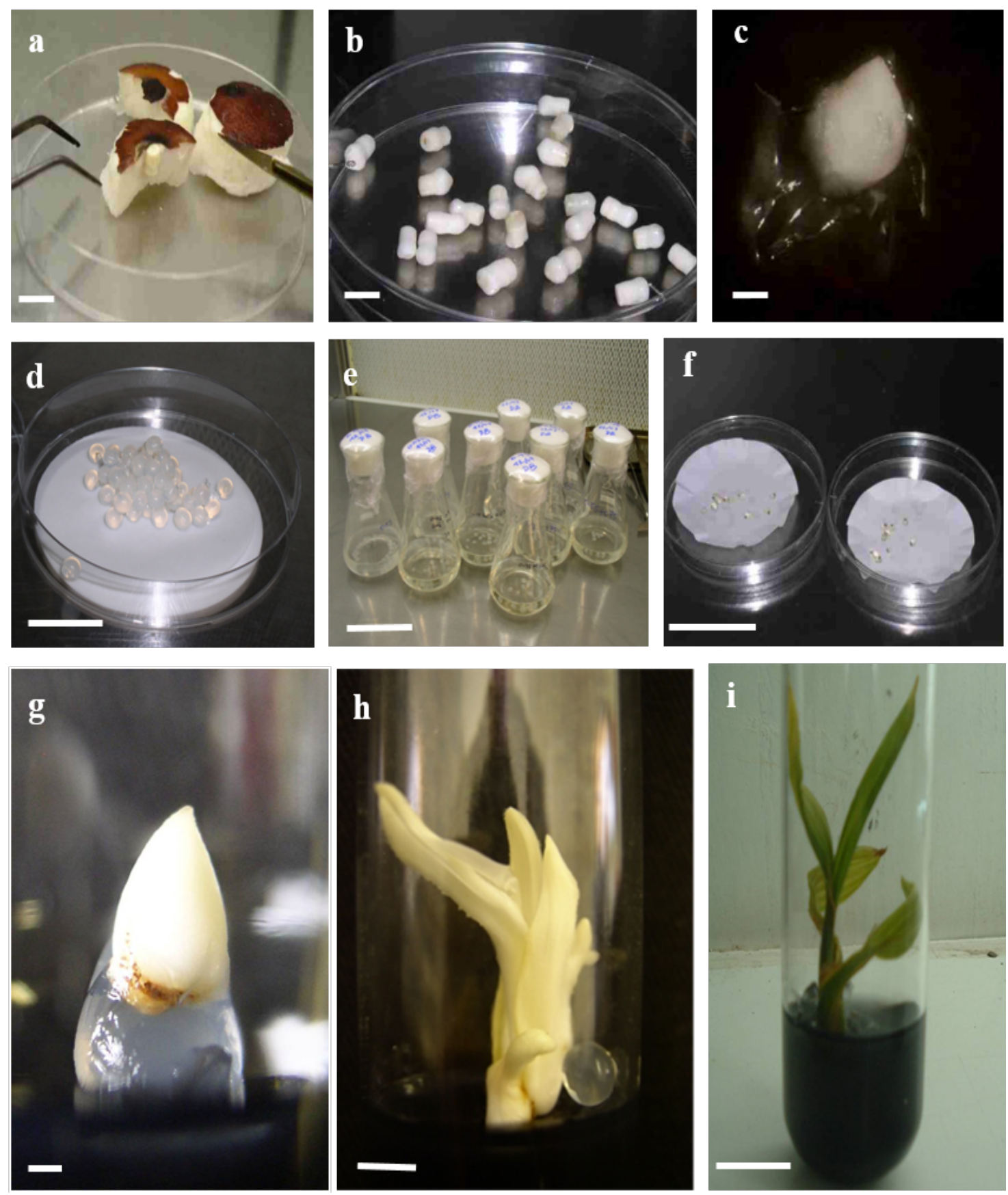

Figure 1. Cryopreservation of coconut plumules using encapsulation/dehydration technique. a. Aseptic dissection of mature zygotic embryos from the endosperm, b.mature zygotic embryo, c. coconut plumula, d. encapsulated plumules, e. sucrose pretreatment, f. encapsulated plumules after dehydration, g. surviving plumula after cryopreservation, $\mathbf{h}$ and $\mathbf{i}$ recovery of plants after cryopreservation. Bars $1 \mathrm{~cm}$ in $\mathbf{a}$ and $\mathbf{b}, 1$ $\mathrm{mm}$ in $\mathbf{c}, 2 \mathrm{~cm}$ in $\mathbf{d}, 8 \mathrm{~cm}$ in e, $5 \mathrm{~cm}$ in $\mathbf{f}, 1 \mathrm{~mm}$ in $\mathbf{g}, 5 \mathrm{~mm}$ in $\mathbf{h}, 2 \mathrm{~cm}$ in $\mathbf{i}$. 
glucose medium were placed in hermetically closed containers carrying 80 or $160 \mathrm{~g}$ silica gel for 48 or $24 \mathrm{~h}$ respectively prior to immersion in liquid nitrogen. Germination percentages of cryopreserved embryos ranged from $13.7 \%$ to $74.7 \%$. In addition to above discussed methods alternative cryopreservation techniques have been developed and tested recently using Malayan Yellow Dwarf (MYD) as a basal material with the purpose of cryobanking (Cueto et al., 2014). Droplet-vitrification of plumular cube (with the plumule and root, $2.5 \times 2.5 \mathrm{~mm}$ ), vitrification of meristematic pole disc (haustorium removed), vacuum-assisted vitrification of intact embryos, and preculturedesiccation of intact embryos have been tried using a systematic approach. Preculturedesiccation of intact embryos and vitrification of plumular cube where samples were progressively loaded with $\mathrm{C} 4-35 \%$ (17.5\% glycerol $+17.5 \%$ sucrose) and C11-60\% (30\% glycerol $+30 \%$ sucrose), followed by dehydration with PVS3 $(50 \%$ glycerol $+50 \%$ sucrose $)$ were recommended for developing a system to get clean in vitro embryos and to optimize the sample preparation procedure for cryopreservation experiments (Cueto et al., 2014). In here these two protocols were proposed for routine implementation of cryobanking for coconut. Assessing the viability of cryopreserved coconut zygotic embryos by electrolytic conductivity and potassium leaching (Gomes-Copeland et al., 2012) was studied in Brazil using embryos of 'Anão Verde do Brasil de Jiqui' (AVeJBr). The mature zygotic embryos pretreated with cryoprotectant with $1.75 \mathrm{~mol} \mathrm{l}^{-1}$ of sucrose and $15 \%$ glycerol for 12 and $16 \mathrm{~h}$ demonstrated lower embryo humidity and increased viability in electrolytic conductivity and potassium leaching tests.

\section{Effect of embryo maturity and duration of storage for cryopreservation}

A study conducted by Chin et al. has reported that immature embryos (5-6 months) survived better $(25 \%)$ than mature embryos after cryopreservation in coconut, but only one of the embryos could be developed into a plantlet after cryopreservation (Chin et al., 1989). The survival of the immature embryos of this study was superior to the results obtained for the mature embryos collected from 9-12 months old nuts. Assy-Bah and Engelmann (1992a) also made an assumption that the immature embryos would be more likely to withstand cryopreservation than mature ones, because of their smaller size and lower degree of differentiation. However, at that time, no protocols have been developed for the use of immature embryos for in vitrocultures, thus use of maturezygotic embryos were encouraged (Assy-Bah and Engelmann, 1992a, b). Moreover, immature zygotic embryos ( $8 \mathrm{~mm}$ in length) are very difficult to excise compared to the excision of mature zygotic embryos (N'Nan et al., 2008).

Factors affecting the cryopreservation of coconut embryos were described by Engelmann et al. (1995). According to him, embryos were used at optimal physiological state with regards to maturity stage and metabolic status. Survival rate of zygotic embryos can be increased by introducing modifications to the recovery conditions. For example, pre-growth treatments on media with high sucrose concentration may increase the tolerance to desiccation, and thus reduce the extent of damage when dehydrating and freezing (Engelmann et al., 1995). Sisunandar et al. (2014) also had employed dehydration methods to investigate the effect of embryo maturity on cryopreservation success in 'Nias Yellow Dwarf', 'Tebing Tinggi Dwarf', 'Takome Tall', and 'Bali Tall' cultivars. It is reported that embryos isolated from an 11 months old fruit gave the highest number of normal seedlings $(\sim 28 \%)$ when compared to counterparts excised from younger fruits (Sisunandar et al. 2014). In addition, Sisunandar et al. (2014) also reported that nuts could be stored up to three weeks prior to embryo isolation. The optimum post-harvest storage duration of nuts before using zygotic embryos in cryopreservation has been highlighted in this study. Post-harvest storage is of great importance in cryopreservation of coconut embryo since, coconut fruits from rare accessions are generally harvested from remote areas and involves long durations for transportation to laboratories. 


\subsection{Plumule}

Plumules are very small $(1 \mathrm{~mm})$ tissues with a shoot apical meristem and leaf primordia (Fig. $1 \mathrm{c}$ ). Cryopreservation of plumules is vital due to the small size and having many meristematic cells (Malaurie et al. 2002). Conservation of plumules is based on the encapsulation techniques in alginate beads (Fig 1 d) due to the small size of the plumule. However, this method involves different treatment combinations such as encapsulation/ osmoprotection/dehydration (Sakai et al., 2000; Malaurie and Borges, 2001; Malaurie et al., 2002) or encapsulation /osmoprotection/ vitrification (Sakai et al., 2000; Malaurie et al., 2002; Malaurie et al., 2004). Furthermore, coconut plumules are free of viral diseases due to their phloem free nature (Maularie et al., 2002; N'Nan et al., 2008). However, plumules are excised from zygotic embryos resulting in the production of clones with unknown performance (N'Nan et al., 2008).

There are many studies focused on assessing the effect of different sucrose concentrations and dehydration regimes for coconut via encapsulation dehydration method. Callus growth has been observed from plumules of the ecotype Laguna Tall after cryopreservation (Hornung et al., 2001). In both non-frozen and frozen plumules, sucrose preculture treatment and silica gel dehydration significantly influenced the frequency of callus formation. The best combination of post-thaw callus growth resulted after incubation of the encapsulated plumules for $72-96 \mathrm{~h}$ in medium containing $0.75 \mathrm{M}$ sucrose followed by desiccation over silica gel for 7-8 h. As a consequence the moisture content (fresh weight basis) decreased to approximately $30 \%$. Postthaw recovery rates in excess of $80 \%$ were recorded (Hornung et al., 2001). This is the only available record so far for initiation of callus after cryopreservation of any coconut tissue.

The first report of an efficient method for coconut plumule cryopreservation through encapsulation-dehydration technique recorded $60 \%$ survival and $20 \%$ leafy shoot development from cryopreserved explants by avoiding the callus pathway in growth regulator free medium (N'Nan et al., 2008). Several different key factors, pretreatment duration ( 2 to $3 \mathrm{ds}$ ), sugar concentration [0.5 M, 0.75 M, $1 \mathrm{M}$, (Fig. $1 \mathrm{e}$ )], dehydration (Fig. $1 \mathrm{f}$ ) period (6 to $24 \mathrm{~h}$ ) and freezing were tested and the highest survival was recorded in the treatment with $16 \mathrm{~h}$ dehydration in $0.75 \mathrm{M}$ sucrose. A combination of abscisic acid (ABA) and sucrose pretreatment improved the survival of cryopreserved coconut plumules of Sri Lanka Tall variety up to $84 \%$ when a encapsulation-dehydration method was used (Bandupriya et al., 2007). In this study, the alginate beads were used to test the effect of different cryoprotection pretreatments which involve mixtures of $0.75 \mathrm{M}$ sucrose and $\mathrm{ABA}$ at concentrations of $0,10,20$ and $40 \mu \mathrm{M}$. Finally, treated material was exposed to silica gel for 16 $\mathrm{h}$ for further dehydration, prior to freezing in liquid nitrogen. Addition of $\mathrm{ABA}$ to the pretreatment medium increased the recovery of cryopreserved plumules from $20 \%$ (N'Nan et al. 2008 ) to $39 \%$ when the plumules were pretreated with $0.75 \mathrm{M}$ sucrose and $40 \mu \mathrm{M}$ ABA (Bandupriya et al., 2007). A study by Malaurie et al. (2006) also demonstrated the importance of adding sorbitol and ABA for successful survival (Fig. $1 \mathrm{~g}$ ) and recovery of encapsulateddehydrated cryopreserved plumules (Fig. $1 \mathrm{~h}$ and i). ABA showed an important significant effect on survival and recovery of the development of the gemmule, in comparison to $0.75 \mathrm{M}$ sucrose. However, this effect was not observed for sorbitol.

Bandupriya et al., $(2010,2014)$ tested a suitable method for transporting/storing of mature zygotic embryos of coconut for subsequent excision of plumules. Three types of conditions were tested: 1) in albumen (solid endosperm) cores, 2) solidified agar medium (SAM) $[0.45 \%(\mathrm{w} / \mathrm{v})$ agar], 3) $\mathrm{KCl}$ solution $\left(16.2 \mathrm{gL}^{-1}\right)$. Cryopreservation of plumules was carried out by encapsulation/dehydration method involving pretreatment with $0.75 \mathrm{M}$ or $1.0 \mathrm{M}$ sucrose and $16 \mathrm{~h}$ dehydration. There was no significant difference in recovery under three conditions tested with cryopreserved plumules. The highest recovery (40\%) after cryopreservation was recorded in the plumules 
pretreated with 1.0 M sucrose and stored in solidified agar (Bandupriya et al., 2010). Incorporation of $20 \mu \mathrm{M} \mathrm{ABA}$ in the sucrose pretreatment step further increased the survival and recovery of plumules transported under different conditions (SAM and $\mathrm{KCl}$ solution), by recording 56\% recovery for plumules transported in SAM that pretreated with $1 \mathrm{M}$ sucrose (Bandupriya et al., 2014).

\section{Establishment of plants to soil}

So far, only very few publications have been reported for the establishment of plants in soil after cryopreservation of coconut embryo (Sajini et al., 2006; Karun and Sajini, 2010; Sisunandar et al. 2010b; Sajini et al. 2011). Since 2001, Central Plantation Crops Research Institute (CPCRI) in India has evaluated the effectiveness of four cryopreservation protocols which are air desiccation, pre-growth desiccation, encapsulation-vitrification and vitrification using zygotic embryos and reported successful recovery of plantlets from these cryopreserved methods (Karun and Sajini, 2010). Amongst these treatments, modified pre-growth and vitrification (PVS3 liquid) technique has produced the highest number of healthy plantlets in poly bags within 11-12 months of culturing and plantlet recovery at the stage of field planting was observed as 23 to $25 \%$ after cryopreservation. Modified pre-growth desiccation method was tested for two exotic accessions of coconut (Fiji Tall and MYD) which resulted a final recovery of $21 \%$ of plantlets in pots in Fiji tall and 28\% in MYD after cryopreservation. Field grown bearing palms are reported in these experiments (Karun and Sajini, 2010). Initial research on coconut (mature zygotic embryos from West Coast Tall (WCT) variety) cryopreservation using pregrowth desiccation method resulted 29\% plantlet recovery in pots (Sajini et al., 2006). Cryopreserved field grown plants from these protocols were similar to the control plants in growth and reproductive biology (Karun and Sajini, 2010). Using a vitrification (PVS3) protocol, CPCRI has obtained $20-25 \%$ of the plants regenerated from cryopreserved embryos those were established in pots (Sajini et al. 2011). Plants regenerated from cryopreserved embryos have shown normal shoot and root growth. All cryopreserved and noncryopreserved control samples were morphologically similar. However, the rate of shoot growth was slower in plantlets coming from cryopreserved embryos (Sajini et al. 2011).

Special apparatus has been developed to dehydrate embryos using dried silica gel and fan forced air (Sisunandar et al. 2010b). This approach gave the higher amount of plants grown in soil (up to $40 \%$ ), by drying the embryos up to $20 \%$ moisture content within eight hours period. This is the first study to record such higher plant development compared to the previously reported methods (Sisunandar et al., 2010b).

\section{Genetic stability of cryopreserved explants}

Even though cryopreservation is considered as the sole available method for the long term preservation of plant material with minimum maintenance, the usefulness of the cryostorage method is totally depends on its capability of producing a genetically stable plant without causing any genetic variation to that particular species (Zarghami et al., 2008).Cryopreservation procedures induce severe stress in plant materials which cause injury at cellular level. But it is not yet clearly proved that the injury caused during cryopreservation is responsible for changing the genetic makeup of plants. Monitoring of geneticstability of plants regenerated from cryopreserved explants has been constantly examined in different plant species (Moukadiri et al., 1999; Hading and Staines, 2001; Ryynanen and Aronen, 2005). The genetic stability of in vitro conserved plants can be examined at morphological, cytological, biochemical or molecular level depending on practical factors such as available expertise, cost, labour and size of germplasm conserved (Harding, 1991; Harding, 2004). So far, only one report on genetic stability upon cryopreservation is available on coconut.

Sisunandar et al. (2010a) found no significant difference in morphological parameters such as length of shoot, number of 
open leaves and number of primary roots after cryopreservation of coconut embryos using a rapid dehydration procedure. Embryos (11 months after pollination) collected from four different varieties (Nias Yellow Dwarf, Nias Green Dwarf, Sagerat Orange Dwarf and Takome Tall) have been tested for morphological parameters after 16 weeks acclimatization period and no significant differences were detected for all four varieties. Long term field trials on cryopreserved coconut plants under the present study were not permitted due to the Quarantine regulations of the Australian Government. It was noted that the plants derived from cryopreserved and noncryopreserved embryos were diploid with a chromosome number of 32 (2n). Furthermore, no significant differences were detected for total short and long arm lengths, and arm length ratios between chromosomes isolated from noncryopreserved and cryopreserved plantlets. The number of chromosomes is aligned with the observations done on coconut cytological studies previously (Abraham and Mathew, 1963; Ninan and Raveendranath, 1975; Perera et al., 2008). When the plants are examined at the molecular level using ten SSR primers, no significant differences were detected for the number of alleles present, the allele frequency and the polymorphism information content (PIC). Furthermore, it was difficult to examine any difference in Global DNA methylation rates between plantlets originating from cryopreserved zygotic embryos and non-cryopreserved embryos. However, in future it is required to assess the genetic and morphological status of palms for a derived from cryopreserved material for certain period of time until their yields are established before coming to a firm conclusion.

\section{Cryopreservation for Germplasm Conservation}

Among elite Indonesian material, the Kopyor mutant is of paramount interest. However, mutants similar to the Kopyor type have been reported from other countries; these include Dikiri pol from Sri Lanka, Macapuno from the Philippines, Coco Gra from Seychelles, ThairuThengai or Nei Thengai or Ghee Thengai from India, Mapharao Khati from Thailand, Sap from Vietnam, Niu Garuk from Papua New Guinea and Pia from Polynesia. This type of coconut has a very limited production with a high price, which is more than 10 times higher the normal fresh coconut nut due to soft and sweet flesh meaning that it is much sought after by customers (Maskromo et al., 2007). There are constraints for the large scale plantation of Kopyor coconuts in Indonesia due to the aberrant nut which is characterized by having a jelly-like, non-functional endosperm tissue that does not allow the proper germination of the zygotic embryo (Mashud et al., 2010). Most of Kopyor plantations originate from spontaneous mutants which appeared randomly amongst non-Kopyor types; the percentage of Kopyor nut produced at random is less than $30 \%$ (Sisunandar, 2013). It is now possible to produce viable Kopyor seedlings through in vitro embryo culture. However, this technique still needs to be developed in order to increase the success rate of seedling production (Sisunandar, 2013).

This mutant cannot be conserved by normal methods such as field gene banks or seed gene banks. Therefore the only alternative conservation method is through cryopreservation. Cryopreservation of zygotic embryos was achieved through the following steps:- a rapid tissue dehydration step using a physical dehydration apparatus prior to storage and a rapid warming step upon recovery followed by acclimatization to soil-supported growth. The best protocol was based on an eight hours rapid dehydration step followed by a rapid cooling step, a rapid warming step and an optimized in vitro culture technique. Following this protocol approximately $20 \%$ of cryopreserved embryo could be returned to normal seedlings growing in soil. Moreover, $23 \%$ of recovered embryos were viable, but unable to produce normal plantlets, as most showed stunted shoots (Sisunandar, 2013).

\section{Histological and ultrastructural studies on cryopreserved material}

Cryopreservation may cause physical or chemical damage to plant tissues due to the stress caused during different stages of the process, which may potentially contribute to 
changes in the of plant cells (Martín and González-Benito, 2005; Harding et al., 2004). Understanding the damage or changes that occur in cryopreserved cells is important part of understanding how dehydration and frozen affect the viability of recalcitrant plant cells. Moreover, histological studies shows the changes occurring during cryopreservation of tissues which are responsible for the death or survival of cryopreserved material (Alla-N'Nan et al., 2014a). Thus histological observations are useful for investigating or confirming the responses of treatments to get better understanding of the structural and ultrastructural changes that occur during cryopreservation.

Few reports have focused on histological appearance of coconut tissues after cryopreservation. Structural and ultrastructural studies show the impact of cryopreservation on cells. Dehydration is critically responsible for the changes and damages occur during cryopreservation (Alla-N'Nan et al., 2014a). The damage caused to cells during cryopreservation can be divided into three stages (Alla-N'Nan et $a l ., 2014 a$ ). The first type of changes are due to general desiccation tolerance such as plasmolysis of cells creating small vacuoles, condensation of chromatin, changes in the conformation of the DNA and the nucleus and stopping of mitosis. The second type of changes occurs as a means of retraction of the cytoplasm inside the cell by increasing the periplasmic volume. The third phase is distinguished by deformation of the cell walls, invagination or the lysis of the plasma membrane which cause the death of cells and the bursting of the nucleus. Second and third phase damages are irreversible and cause death of tissues. N'Nan et al. (2008) suggests that the changes in the nucleus which becomes compact and deeply stained may be due the halted functions of the nucleus which results in no transcription or protein synthesis. Cryopreservation of coconut plumules using the optimal conditions ( $1 \mathrm{M}$ sucrose pretreatment and $16 \mathrm{~h}$ dehydration) has shown that cells which remained alive are grouped at the periphery of the meristem dome (N'Nan et al., 2008). ABA also has shown a beneficial effect by improving tolerance to dehydration and freezing stress. Induced alterations in cells and tissues were associated with their ability to recover and could be reversible (Malaurie et al., 2006). Cellular integrity of cryopreserved embryos was retained by a vitrification method after unloading treatment with $1.2 \mathrm{M}$ sucrose (Sajini et al., 2011). In the other hand, cell wall structure of cryopreserved explants was disturbed and damaged when embryos were transferred to unloading medium with a lower sucrose concentration $(0.6 \mathrm{M}$ and $0.8 \mathrm{M})$.

\section{Limitations in coconut cryopreservation}

The production of abnormal seedlings is a common side effect of cryopreservation and has been reported in many recalcitrant species (Berjak et al., 2000). This phenomenon can also be observed in coconut (Engelmann and AssyBah, 1992b; Sisunandar et al., 2010a, 2010b, 2012, 2013). However, conditions for in vitro culture were not well developed at that time and only few fully developed, normal plantlets could be obtained. The most likely reason for the occurrence of abnormal seedlings in cryopreserved embryos is discussed by Berjak et al. (2000). According to these authors, the root meristem is more protected by other compact cells than in the shoot meristem. Therefore the cells of the shoot apical meristem are more vulnerable for damage during dehydration treatment and liquid nitrogen application than the root cells. Some embryos of recalcitrant species failed to produce normal shoots due to excessive freezing injury during the cryopreservation process (Wesley-Smith et al., 2004). Therefore research should be undertaken with the aim of improving the rate of seedling development (Sisunandar, 2013). Cryogenic storage of coconut also has some other limitations such as, when used in breeding programs, phenotypic characterization is difficult due long juvenile period of the recovered propagule before it reach reproductive maturity (Volk, 2010). According to the limited work done on different coconut accessions, it is clear that the cryopreservation protocol needs to be mastered for each coconut variety separately. This is very tedious and challenging. Problems related to coconut tissue culture, such as, difficulties in in vitro culture due to hard tissues, 
browning of the tissues due to high polyphenols and consequent death are also indirectly affecting the success of cryopreservation techniques.

\section{Future directions and Conclusion}

The work done so far indicates the possibility of long-term coconut preservation even though the success rate is low. Previously, somatic embryos could not be used for germplasm conservation because in vitro propagation of coconut using somatic embryogenesis was not mastered. However, a successful procedure for callogenesis and somatic embryogenesis through unfertilized ovary explants in coconut has been reported for the first time in Sri Lanka (Perera et al., 2007) and has indicated its high potential for using as a novel explants during for embryogenesis (Perera et al., 2007; Vidhanaarchchi et al., 2013). Therefore, cryopreservation research needs to be focused on other plant material such as somatic embryos and embryogenic calli.

When considering plumules, it is the best option for safe cryopreservation to avoid diseases like Lethal Yellowing (LY) (N'Nan et al., 2008; Alla-N'Nan et al., 2014b). Since a plumule has only provascular strands without differentiated phloem it has much less chance to transmit LY causing phytoplasma, which are normally present in the phloem (Frison et al., 1993; Malaurie, 2001; Hocher et al., 2004). Furthermore, cryotherapy of shoot tips is another method of pathogen eradication (Wang et al., 2009) and has been tested for several crops such as cucumber and banana (Helliot et al., 2002); potato (Wang et al., 2006); sweet potato (Wang et al., 2008) by cryopreserving the shoot tips. This has not been tested in coconut so far.

Even though the recovery percentages recorded in coconut so far are low, in the context of germplasm conservation, these results are considered to be promising (Dussert et al., 2003). Cryopreservation has still only been tested on a limited number of coconut varieties. Therefore attempts needs to be initiated to screen the best protocol for the conservation of the maximum number of coconut varieties and accessions. This will enable coconut cryopreservation to become a successful story in the near future.

\section{Acknowledgement}

This work was supported by the National Science Foundation, Sri Lanka under the Grant No. RG/2014/BT/01. Our special thanks go to Prof. J. M. Dunwell for reading the manuscript critically.

\section{References}

Abraham, A. and Mathew, P.M. 1963. Cytology of coconut endosperm, Annals of Botany 27: 505-513.

Ai, P.F., Lu, L.P. and Song, J.J. 2012. Cryopreservation of in vitro-grown shoottips of Rabdosia rubescens by encapsulation-dehydration and evaluation of their genetic stability. Plant Cell Tissue and Organ Culture 108: 381-387.

Alla-N'Nan, O., Tiécoura, K., Bi, S.G., Verdeil, J-L. and Malaurie, B. 2014a. Ultrastructural changes during cryopreservation of plumules and embryos of coconut (Cocos nucifera L.). International Journal of Agronomy and Agricultural Research 5 (6): 103-115.

Alla-N'Nan, O., Bi, S.G., Tiécoura, K. and Konan, J-L.K. 2014b. Use of plumules cryopreservation to save coconut germplasm in areas infected by lethal yellowing. African Journal of Biotechnology 13:1702-1706.

Assy-Bah, B. and Engelmann, F. 1992a. Cryopreservation of immature embryos of coconut (Cocos nucifera L.). CryoLetters 13: $67-74$.

Assy-Bah, B. and Engelmann, F. 1992b. Cryopreservation of mature embryos of coconut (Cocos nucifera L.) and subsequent regeneration of plantlets. CryoLetters 13: 117-126.

Bajaj, Y.P.S. 1984. Induction of growth in frozen embryos of coconut and ovaries of citrus. Current Science 53: 1215-1216. 
Bajaj, Y.P.S. 1995. Cryopreservation of plant cell, tissue and organ culture for the conservation of germplasm and biodiversity. In: Y.P.S Bajaj (Ed.) Biotechnology in Agriculture and Forestry, Cryopreservation of Plant Germplasm I, Springer-Verlag, Berlin Heidelberg. 32: 3-28.

Bandupriya, H.D.D., Fernando, S.C., Verdeil, JL. and Malaurie, B. 2007. Effect of abscisic acid on survival and recovery of cryopreserved plumule explants of coconut (Cocos nucifera L.). Cocos 18: $45-51$

Bandupriya, H.D.D., Fernando, S.C., Verdeil, JL. and Malaurie B. 2010. Cryopreservation of encapsulated plumules of coconut: effect of transport/ store conditions. AsPac Journal of Molecular. Biology and Biotechnology 18 (1): 135-137.

Bandupriya, H.D.D., Fernando, S.C., Verdeil, JL. and Malaurie, B. 2014. Efficient method of transporting coconut (Cocos nucifera L.) zygotic embryos for cryopreservation of plumules by encapsulation/dehydration. Cord 30 (2): 19-30.

Benson, E.E., Reed, B.M., Brennan, R.M., Clacher, K.A. and Ross, D.A. 1996. Use of thermal analysis in the evaluation of cryopreservation protocols for Ribes nigrum L. germplasm. CryoLetters 17: 347-362.

Berjak, P., Walker, M., Mycock, D.J., WesleySmith, J., Watt, P. and Pammenter, N.W. 2000. Cryopreservation of recalcitrant zygotic embryos. In: F. Engelmann, H. Takagi (Eds.), Cryopreservation of Tropical Plant Germplasm. Current Progress and Application, Japan International Research Center for Agricultural Sciences, Tsukuba, Japan / International Plant Genetic Resources Institute, Rome, Italy. pp. 140 - 155.

Chaudhury, R. 2003. Cryopreservation: Principles and Practices. Conservation biotechnology of plant germplasm. In: B.B. Mandal, R. Chaudhury, F. Engelmann, B. Mal, K.L. Tao, B.S. Dhillon (eds.), Proceedings of regional training course on in vitro conservation and cryopreservation of plant germplasm, NBPGR, New Delhi, India. pp. 179-186.

Chin, H.F. and Roberts, E.H. 1980. Recalcitrant crop seeds. Tropical Press SND, DHDI, Kuala Lumpur.

Chin, H.F., Krishnapillay, B. and Hor, Y.L. 1989. A note on the cryopreservation of embryos of coconut (Cocos nucifera L. var. Mawa). Pertanika 12:183-186.

Coconut Statistical Year Book (2014). The Asian and Pacific Coconut Community (APCC).

Crowe, J.H., Crowe, L.M., Carpenter, J.F., Rudolph, A.S., Wistrom, C.A., Spargo, B.J. and Anchordoguy, T.J. 1988. Interactions of sugars with membranes. Biochimica et Biophysica Acta 947: 36784.

Cueto, C, Rivera, R.L., Kim, H.H., Kong, H.J., Baek, H.J., Sebastian, L. and Park, H.J. 2014. Development of Cryopreservation Protocols for Cryobanks of Coconut Zygotic Embryos. In II International Symposium on Plant Cryopreservation 1039: $297-302$.

Dussert, S., Engelmann, F. and Noirot, M. 2003. Development of probabilistic tools to assist in the establishment and management of cryopreserved plant germplasm collections. CryoLetters 24: 149-160.

Engelmann, F. 1991. In vitro conservation of tropical plant germplasm - a review. Euphytica 57: 227-243.

Engelmann, F., Dumet, D., Chabrillange, N., Abdelnour-Esquivel, A., Assy-Bah, B., Dereuddre, J. and Duval, Y. 1995. Factors affecting the cryopreservation of coffee, coconut and oil palm embryos. Plant Genetic Resources Newsletter 103: 27-31. 
Engelmann, F. 1997. In vitro conservation methods. In: B.V. Ford-Lloyd, J.H. Newbury, and J.A. Callow (eds.), Biotechnology and plant genetic resources: conservation and use. CABI, Wallingford. pp. 119-162.

Engelmann, F. 1999. Cryopreservation of coconut germplasm. In: C. Oropeza, J-L. Verdeil, G.R. Ashburner, R. Cardeña, J.M. Santamaria (eds.), Current Advances in Coconut Biotechnology Kluwer Academic Publishers, Dordrecht. pp. 289-296.

Engelmann, F. 2000. Importance of cryopreservation for the conservation of plant genetic resources. In: F. Engelmann, H. Takagi (eds.), Cryopreservation of tropical plant germplasm-current research progress and applications, JIRCAS, Tsukuba. pp. 8-20.

Engelmann, F. 2003. Plant cryopreservation: Current Status, Prospects and Limitatons. Conservation biotechnology of plant germplasm. In: B.B. Mandal, R. Chaudhury, F. Engelmann, B. Mal, K.L. Tao, B.S. Dhillon (eds.). Proceedings of regional training course on in vitro conservation and cryopreservation of plant germplasm, NBPGR, New Delhi, India. pp. 223-228.

Engelmann, F. 2004. Plant cryopreservation: progress and prospects. In vitro Cellular and Developmental Biology - Plant 40: 427-433.

Engelmann, F., Malaurie, B., N'Nan, O. and Borges, M. 2005. Status of cryopreservation research in coconut. In: P. Batugal, V.R. Rao, J. Oliver (eds.), Coconut Genetic Resources IPGRI-APO, Serdang, Malaysia. pp. 142-148.

Engelmann, F. 2011. Use of biotechnologies for the conservation of plant biodiversity. In Vitro Cellular and Developmental Biology-Plant 47 (1): 5-16.

Engelmann, F. and Dussert, S. 2013. Cryopreservation. In: Conservation of
Tropical Plant Species, Springer New York. pp. 107-119.

Fabre, J. and Dereuddre, J. 1990. Encapsulationdehydration: A new approach to cryopreservation of Solanum shoot tips. CryoLetters 11:413-426.

Feng, C.H., Cui, Z.H., Li, B.Q., Chen, L., Ma, Y.L., Zhao, Y.H. and Wang, Q.H. 2013. Duration of sucrose preculture is critical for shoot regrowth of in vitro-grown apple shoot-tips cryopreserved by encapsulation-dehydration. In vitro Cellular and Developmental Biology 112: 369-378.

Frison, E.A., Putter, C.A.J. and Diekmann, M. (eds.) 1993. FAO/IBPGR Technical guidelines for the safe movement of coconut germplasm. FAO/IBPGR, Rome.

Gomes-Copeland, K.K.P., Lédo, A.D.S., Almeida, F.T.C.D., Miranda, R.P. and Santos, I.R.I. 2012. Assessing the viability of cryopreserved coconut zygotic embryos by electrolytic conductivity and potassium leaching. Pesquisa. Agropecuária Brasileira 47 (1): 8-13.

Harding, K. 1991. Molecular stability of the ribosomal RNA genes in Solanum tuberosum plants recovered from slow growth and cryopreservation. Euphytica 55: 141-146.

Harding, K. and Staines, H. 2001. Biometric analysis of phenotypic characters of potato shoot-tips recovered from tissue culture, dimethyl sulphoxide treatment and cryopreservation. CryoLetters 22: 255262.

Harding, K. 2004. Genetic integrity of cryopreserved plant cells: a review. CryoLetters 25:3-22.

Harding, K., Day, J.G., Lorenz, M. Timmermann, H, Friedl, T. Bremner, D.H. and Benson, E.E. 2004. Introducing the concept and application of vitrification for the cryo-conservation of algae - A minireview. Nova Hedwigia 79: 207-226. 
Helliot, B., Panis, B., Poumay, Y., Swennen, R., Lepoivre, P. and Frison, E. 2002. Cryopreservation for the elimination of cucumber mosaic and banana streak viruses from banana (Musa spp.). Plant Cell Reports 20 (12): 1117-1122.

Hocher, V., Verdeil, J-L. and Malaurie, B. 2004. Cocos nucifera Coconut. In: R.E. Litz (ed.), Biotechnology of Fruit and Nut Crops, Chapter 4-1, Arecaceae, Biotechnology in Agriculture Series N.29, CABI Publishing Tropical Research and Education Center, Univ. of Florida, USA. pp. 90-112.

Hornung, R., Domas, R. and Lynch, P.T. 2001. Cryopreservation of plumular explants of coconut (Cocos nucifera L.) to support programmes for mass clonal propagation through somatic embryogenesis. CryoLetters 22: 211-220.

Janeiro, L.V., Ballester, A. and Vieitez, A.M. 1997. In vitro response of encapsulated somatic embryos of camellia. Plant Cell Tissue and Organ Culture 51: 119-125.

Jayasingha, J.A.S.S.C., Weerakoon, S.R. and Weerakoon, L.K. 2002. Studies on cryopreservation of mature zygotic embryos of coconut (Cocos nucifera L.). Proceedings of Sri Lanka Association for the Advancement of Science 58: 66.

Jekkel, Z., Gyulai, G., Kiss, J., Kiss, E. and Heszky, L.E. 1998. Cryopreservation of horse-chestnut (Aesculus hippocastanum L.) somatic embryos using three different freezing methods. Plant Cell Tissue and Organ Culture 52: 193-197.

Karun, A. Sajini, K.K. and Parthasarathy, V.A. 2005. Cryopreservation of mature coconut zygotic embryos by desiccation method. Cord 21: 13-19.

Karun, A. Sajini, K.K., Kumaran, P.M. and Samsudheen, K. 2006. Cryopreservation of coconut (Cocos nucifera L.) pollen. Journal of Plantation Crops 34: 568-571.

Karun, A. and Sajini, K. K. 2010. Cryopreservation of Coconut Zygotic
Embryos and Pollen. Tech. Bulletin No. 57. Central Plantation Crops Research Institute, Kasaragod, Kerala pp 18.

Karun, A., Sajini, K.K., Niral, V., Amarnath, C.H., Remya, P., Rajesh, M.K. and Engelmann, F. 2014. Coconut (Cocos nucifera L.) pollen cryopreservation. CryoLetters 35 (5): 407-417.

Kartha, K.K. and Engelmann, F. 1994. Cryopreservation and germplasm storage. In: I.K. Vasil, T.A. Thorpe (eds.), Plant cell and tissue culture, Kluwer, Dordrecht. pp. $195-230$.

Kaviani, B. 2011. Conservation of plant genetic resources by cryopreservation. Australian Journal of Crop Science 5 (6): 778.

Kim, H.H., Lee, Y.G., Shin, D.J, Ko, H.C., Gwag, J.G., Cho, E.G. and Engelmann, F. 2009. Development of alternative plant vitrification solutions in dropletvitrification procedures. CryoLetters $\mathbf{3 0}$ (5): 320-334.

Kong, L. and Aderkas, P.V. 2011. A novel method of cryopreservation without a cryoprotectant for immature somatic embryos of conifer. Plant Cell Tissue and Organ Culture 106: 115-125.

Langis, R., Schnabel, B., Earle, E.D. and Steponkus, P.L. 1989. Cryopreservation of Brassica campestris L. cell suspensions by vitrification. CryoLetters 10:421-428.

Lu, Z.W., Popova, E.V., Wu, C.H., Lee, E.J., Hahn, E.J. and Paek, K.Y. 2009. Cryopreservation of Ginkgo biloba cell culture: Effect of pretreatment with sucrose and ABA. CryoLetters 30 (3): 232-243.

Machado, C.D.A., Moura, C.R.F., Lemos, E.E.P.D., Ramos, S.R.R., Ribeiro, F.E. and Lédo, A.D.S. 2014. Pollen grain viability of coconut accessions at low temperatures. Acta Scientiarum. Agronomy 36 (2): 227-232.

Malaurie, B. 2001. Medium- and long-term conservation and safe international 
exchange of germplasm from food and cash tropical crops. Acta Horticulturae 560: 69-77.

Malaurie, B. and Borges, M. 2001. Cryopreservation of coconut (Cocos nucifera L.) plumules by encapsulation/ dehydration. In International Workshop on Plant Biotechnology-Plant Breeding and Biotechnology, Ciego de Avila 16 (20): 59.

Malaurie, B., Borges, M. and N'Nan, O. 2002. Research of an optimal cryopreservation process using encapsulation/ osmoprotection/ dehydration and encapsulation/ osmoprotection / vitrification techniques on caulinary meristems of coconut (Cocos nucifera L.). Burotrop Bulletin 20:16.

Malaurie, B., N'Nan, O., Borges, M., Bandupriya, H.D.D., Perera, P., Fernando, S.C., Hocher, V. and Verdeil, J-L. 2004. The use of biotechnology for conservation and dissemination of coconut genetic resources: an assessment of the IRD/Cirad implication. Proc. of International Conference of the Coconut Research Institute of Sri Lanka - Part I. (Eds: T.S.G. Peiris and C.S. Ranasinghe). The Coconut Research Institute of Sri Lanka, Lunuwila 61150, Sri Lanka. pp. 233-253.

Malaurie, B., Bandupriya, H.D.D., Fernando, S.C. and Verdeil, J-L, 2006. Optimisation du procédé de cryoconservation de la plumule de cocotier. Les Actes du BRG 6: 449-468.

Mallon, R., Bunn, E., Turner, S.R. and Gonzalez, M.L. 2008.Cryopreservation of Centaurea ultreiae (Compositae) a critically endangered species from Galica (Spain). CryoLetters 29: 363-370.

Mandal, B.B. 2003. Cryopreservation techniques for Plant Germplasm Conservation. Conservation biotechnology of plant germplasm. In: B.B. Mandal, R. Chaudhury, F. Engelmann, B. Mal, K.L. Tao, B.S. Dhillon (eds.), Proceedings of regional training course on in vitro conservation and cryopreservation of plant germplasm, NBPGR, New Delhi, India. pp. 187-207.

Martín, C. and González-Benito, M.E. 2005. Survival and genetic stability of Dendranthema grandiflora Tzvelev shoot apices after cryopreservation by vitrification and encapsulationdehydration. Cryobiology 51: 281-289.

Mashud, N. 2010. Pengembangan metode kultur embryo kelapa kopyor yang lebih efisien (30\%). Balai Penelitian Tanaman Kelapa dan Palma Lain, Manado.

Maskromo, I., Mashud, N. and Novarianto, H. 2007. Potensi pengembangan kelapa kopyor di Indonesia. Warta Penelitian dan Pengembangan 13: 4-6.

Mazur, P. 1984. Freezing of living cells: mechanisms and implications. American Journal of Physiology-Cell Physiology 247(3):125-142.

Ming-Hua, Y. and Sen-Rong, H. 2010. A simple cryopreservation protocol of Dioscorea bulbifera L. embryogenic calli by encapsulation-vitrification. Plant Cell Tissue and Organ Culture 101:349-358.

Mortazavi, S.M.H., Arzani, K. and Moieni, A. 2010. Optimizing storage and In vitro germination of date palm (Phoenix dactylifera) pollen. Journal of Agricultural Science and Technology 12: 181-189.

Moukadiri, O., Deming, J., O'Connor, J.E. and Carnejo, M.J. 1999. Phenotypic characterization of the progenies of rice plants derived from cryopreserved calli. Plant Cell Reports 18:625-632.

Nguyen, Q.T., Bandupriya, H.D.D., Lo'pezVillalobos, A., Sisunandar, S., Foale, M. and Adkins, S.W. 2015. Tissue culture and associated biotechnological interventions for the improvement of coconut (Cocos nucifera L.): a review. Planta 242(5): 1059-1076. 
Ninan, C.A. and Raveendranath, T.G. 1975. A study of karyotype of spicata and typica varieties of coconut and its bearing on the breeding behavior of spicata palms, New Botanist (India) 2: 81-87.

Nishizawa, S., Sakai, A., Amano, A.Y., Matsuzawa, T. 1993. Cryopreservation of asparagus (Asparagus officinalis L.) embryogenic suspension cells and subsequent plant regeneration by vitrification. Plant Science 91:67-73.

N'Nan, O. 1997. Recherche d'une méthode de déshydratation simple, favorable à la survie et à la régénération des embryons zygotiques matures cryoconservés de cocotier (Cocos nucifera L.). Diplôme d'Etudes Approfondies, Université Abidjan-Cocody.

N'Nan, O., Borges, M., Verdeil, J-L., Hocher, V. and Malaurie, B. 2003. Are caulinary meristems suitable for cryopreservation of coconut (Cocos nucifera L.) with encapsulation/dehydration technique? Histological studies, a way to find the good range of pretreatments. Burotrop Bulletin 20: 17.

N'Nan, O., Hocher, V., Verdeil, J-L., Konan, JL.K, Ballo, K., Mondeil, F. and Malaurie, B. 2008. Cryopreservation by encapsulation-dehydration of plumules of coconut (Cocos nucifera L.). CryoLetters 29 (4): 339-350.

N'Nan, O., Borges, M., Konan J-L.K., Hocher, V., Verdeil, J-L., Tregear, J., N'guetta, A.S.P., Engelmann, F. and Malaurie, B. 2012. A simple protocol for cryopreservation of zygotic embryos of ten accessions of coconut (Cocos nucifera L.). In vitro Cellular and Developmental Biology-Plant 48:160-166.

Panis, B., Swennen, R. and Engelmann, F. 2001. Cryopreservation of plant germplasm. Acta Horticulturae 650: 79-86.

Panis, B., Piette, B. and Swennen, R. 2005. Droplet vitrification of apical meristems: a cryopreservation protocol applicable to all Musaceae. Plant Science 168:45-55.

Panis, B. and Lambardi, M. 2006. Status of cryopreservation technologies in plants (crops and forest trees). In The Role of Biotechnology for the Characterization and Conservation of Crop, Forest, Animal and Fishery Genetic Resources in Developing Countries. (Eds.) FAO. Turin, Italy. pp. 43-54.

Paunescu, A. 2009. Biotechnology for endangered plant conservation: a critical overview. Romanian Biotechnological Letters 14: 4095-4103.

Perera, P.I.P., Hocher, V., Verdeil, J., Doulbeau, S., Yakandawala, D.M.D. and Weerakoon, L.K. 2007. Unfertilized ovary: a novel explant for coconut (Cocos nucifera L.) somatic embryogenesis. Plant Cell Reports 26: 1-8.

Perera, P.I.P., Wickremasinghe, I.P. and Fernando, W.M.U. 2008. Morphological, cytogenetic and genotypic differences between Spicata and ordinary tall coconut (Cocos nucifera L.), Journal of National Science Foundation of Sri Lanka 36: 103108.

Popova, E.V., Lee, E.J., Wu. C.H., Eun-Joo Hahn, E.J. and Paek, K.Y.A. 2009. Simple method for cryopreservation of Ginkgo biloba callus. Plant Cell Tissue and Organ Culture 97:337-343.

Rao, N.K. 2004. Plant genetic resources: advancing conservation and use through biotechnology. African Journal of biotechnology 3(2): 136-145.

Reed, B.M. and Uchendu, E. 2008. Controlled rate cooling. In: B.M. Reed (Ed.), Plant cryopreservation: a practical guide, Springer, Berlin. pp. 77-92

Roberts, E.H. 1973. Predicting the storage life of seeds. Seed Science and Technology 1: 499-514.

Ryynänen, L. and Aronen, T. 2005. Genome fidelity during short-and long-term tissue 
culture and differentially cryostored meristems of silver birch (Betula pendula). Plant Cell, Tissue and Organ Culture 83(1): 21-32.

Sajini, K.K., Karun, A. and Kumaran, P.M.2006. Cryopreservation of coconut (Cocos nucifera L.) zygotic embryos after pre-growth desiccation. Journal of Plantation Crops 34: 576-581.

Sajini, K.K., Karun, A., Amarnath, C.H., and Engelmann, F. 2011. Cryopreservation of coconut (Cocos nucifera L.) zygotic embryos by vitrification. CryoLetters 32(4): 317-328.

Sakai, A, Kobayashi, S. and Oiyama, I.E. 1990. Cryopreservation of nucellar cells of navel orange (Citrus sinensis Osb. var. brasiliensis Tanaka) by vitrification. Plant Cell Reports 9: 30-33.

Sakai, A., Matsumoto, T., Hirai, D. and Nino, T. 2000. Newly developed encapsulationdehydration protocol for plant cryopreservation. CryoLetters 21: 53-62.

Sakai, A. and Engelmann, F. 2007. Vitrification, encapsulation-vitrification and dropletvitrification: a review. CryoLetters 28(3): 151-172.

Sen-Rong, H. and Ming-Hua, Y. 2009. Highefficiency vitrification protocols for cryopreservation of in vitro grown shoot tips of rare and endangered plant Emmenopterys henryi Oliv. Plant Cell Tissue and Organ Culture 99: 217-226.

Sen-Rong, H. and Ming-Hua, Y. 2012. A simple and efficient protocol for cryopreservation of embryogeniccalli of the medicinal plant Anemarrhena asphodeloides Bunge by vitrification. Plant Cell Tissue and Organ Culture 109: 287-296.

Sisunandar, Rival, A., Turquay. P., Samosir, Y., and Adkins, S.W. 2010a. Cryopreservation of coconut (Cocos nucifera L.) zygotic embryos does not induce morphological, cytological or molecular changes in recovered seedlings. Planta 232(2): 435-447.
Sisunandar, Peter, A., Sopade, P.A., Samosir, Y.M.S., Rival, A. and Adkins, S.W. 2010b. Dehydration improves cryopreservation of coconut (Cocos nucifera L.). Cryobiology 61: 289-296.

Sisunandar, Sopade, P.A., Samosir, Y., Rival, A. and Adkins, S. 2012.Conservation of coconut (Cocos nucifera L.) germplasm at sub-zero temperature. CryoLetters 33: 465- 475 .

Sisunandar, 2013. Cryopreservation for Germplasm Conservation: Progress Report on Indonesian Elite Mutant Coconut "Kopyor". In Proceeding International Conference on Global Resource Conservation and 10th Indonesian Society for Plant Taxonomy Congress Brawijaya University (No. 1).

Sisunandar, Novarianto, H., Mashud, N., Samosir, Y.M. and Adkins, S.W. 2014. Embryo maturity plays an important role for the successful cryopreservation of coconut (Cocos nucifera). In Vitro Cellular and Developmental BiologyPlant 50(6): 688-695.

Steponkus, P.L. 1985. Cryobiology of isolated protoplasts: Applications to plant cell cryopreservation. In: K.K. Kartha (Ed.), Cryopreservation of plant cells and organs, CRC Press, Boca Raton, Florida. pp. 49-60.

Uragami, A., Sakai, A., Nagai, M. and Takahashi, T. 1989. Survival of cultured cells and somatic embryos of Asparagus officinalis L. cryopreserved by vitrification. Plant Cell Reports 8: 418421.

Vidhanaarachchi, V.R.M., Fernando, S.C., Perera, P.I.P. and Weerakoon, L.K. 2013. Application of un-fertilized ovary culture to identify elite mother palms of Cocos nucifera L. with regenerative potential. Journal of the National Science Foundation of Sri Lanka 41 (1): 29-34.

Volk, G.M. 2010. Application of Functional Genomics and Proteomics to Plant 
Cryopreservation. Current Genomics. 11: 24-29.

Wang, Q., Mawassi, M., Sahar, N., Li, P., Violeta, C.T., Gafny, R., Sela, I., Tanne, E. and Perl, A. 2004. Cryopreservation of grapevine (Vitis spp.) embryogenic cell suspensions by encapsulationvitrification. Plant Cell Tissue and Organ Culture 77: 267-275.

Wang, Q., Liu, Y., Xie, Y. and You, M. 2006. Cryotherapy of potato shoot tips for efficient elimination of Potato leafroll virus (PLRV) and Potato virus Y (PVY). Potato Research 49(2): 119-129.

Wang, Q.C., and Valkonen, J.P.T. 2008. Elimination of two viruses which interact synergistically from sweet potato by shoot tip culture and cryotherapy. Journal of Virological Methods 154(1): 135-145.

Wang, Q.C., Panis, B., Engelmann, F., Lambardi, M., and Valkonen, J.P.T. (2009). Cryotherapy of shoot tips: a technique for pathogen eradication to produce healthy planting materials and prepare healthy plant genetic resources for cryopreservation. Annals of Applied Biology 154(3): 351-363.

Wesley-Smith, J., Walter, C., Berjak, P. and Pammenter, N.W. 2004. The influence of water content, cooling and warming rate upon survival of embryonic axes of Poncirus trifoliata L. CryoLetters 25: 129138.

Withers, L.A., Engelmann, F. 1998. In vitro conservation of plant genetic resources. In: A. Altman (ed). Biotechnology in agriculture. Marcel Dekker Inc., New York. pp. 57-88.

Zarghami, R., Pirseyedi, S.M., Hasrak, S.H. and Pakdaman, B.S. 2008. Evaluation of genetic stability in cryopreserved Solanum tuberosum, African Journal of Biotechnology 7: 2798-2802. 